\title{
Myths about modern and traditional contraceptives held by women in Minia, Upper Egypt
}

\author{
Ehab Eshak ${ }^{1,2}$
}

${ }^{1}$ Department of Public Health and Preventive Medicine, Faculty of Medicine, Minia University, Minia City, Egypt. ${ }^{2}$ Public Health Department of Social Medicines, Graduate School of Medicine, Osaka University, Osaka, Japan. (Correspondence to: Ehab Eshak: ehabsalahı@yahoo.com).

\begin{abstract}
Background: Misconceptions about modern contraceptives affect their use in low- and middle-income countries.

Aims: This study aimed to determine the prevalence of myths about modern contraceptives and their association with ever and current use of contraceptives by women in Minia, Upper Egypt.

Methods: This was a cross-sectional study of 1212 married Egyptian women aged 18-49 years attending urban and rural health centres in Minia. Data were collected using a structured interview questionnaire and analysed by logistic regression analysis; odds ratios (OR) and $95 \%$ confidence intervals (CI) were calculated.

Results: Most of the women (88.7\%) had one or more misconceptions about contraceptives. The most prevalent misconceptions were that birth control pills cause cancer and intrauterine devices (IUDs) can penetrate the uterus and move to the heart. The current use of birth control pills and IUDs was significantly lower in women with misguided beliefs than those without such beliefs; adjusted OR $=0.59$ (95\% CI: 0.37-0.90) and adjusted OR $=0.50$ (95\% CI: $0.34-0.76$ ) respectively. Belief in an increasing number of myths was associated with lower odds of ever use of birth control pills: OR $=0.72$ (95\% CI: 0.57-0.96), OR = 0.61 (95\% CI: 0.43-0.91), OR = 0.48 (95\% CI: 0.29-0.69) and OR = 0.43 (95\% CI: $0.24-0.63$ ) in women with 1, 2, 3 and $\geq 4$ misconceptions versus those with none.
\end{abstract}

Conclusions: Myths about contraceptives are common in women in Minia and may have a significant effect on their choice and use of contraceptive method. Reproductive health programmes to refute such misguided beliefs are recommended.

Keywords: reproductive health, contraception, prevalence, female, Egypt

Citation: Eshak E. Myths about modern and traditional contraceptives held by women in Minia, Upper Egypt. East Mediterr Health J. 2020;26(4):417425. https://doi.org/10.26719/emhj.19.053

Received: 02/05/18; accepted: 13/08/18

Copyright @ C World Health Organization (WHO) 2020. Open Access. Some rights reserved. This work is available under the CC BY-NC-SA 3.0 IGO license (https://creativecommons.org/licenses/by-nc-sa/3.o/igo).

\section{Introduction}

According to the Egyptian Ministry of Health and Population, the proportion of contraceptives users in 2014 was still less than $50 \%$ and was far below the corresponding proportion of married women $(>80 \%$ ) who desire no more children (1). With the rapid growth of the Egyptian population from 20.8 to 98.1 million inhabitants in the past 50 years (2), strenuous efforts have been made to promote maternal and child health through family planning programmes that empower families to make informed decisions on the number of children and interval between children they want and to reduce unintended pregnancies.

The use and type of contraceptives should be guided by women's health status (3). However, in low- and middle-income countries, culture and other non-medical factors have been shown to play an important role in women's decision to use contraceptives (4). Despite evidence on the positive effect of contraceptive use, not only on controlling fertility but also on women's health, family welfare and social life in general (5), myths and misconceptions about modern contraceptives are still prevalent in such communities (6-8) and may prevent their use, which can lower general health of the women
(7-9) and may be obstacles to effective family planning programmes $(7,8,10)$.

Myths and misconceptions about contraceptives are very common in deprived areas and low- and middleincome communities (4,6-8,11,12). In Egypt, especially in rural areas, poverty, illiteracy and misguided religious beliefs have created a culture and environment that have helped spread misinformation about modern contraceptives since their introduction in $1967(13,14)$.

Evidence on these issues is from the 1980 s and more recent studies are lacking. Furthermore, those earlier studies focused on misconceptions about oral contraceptive pills only. For example, one study showed that $57 \%$ and $52 \%$ of urban and rural Egyptians respectively believed that using oral contraceptive pills had substantial health risks (15). The most prevalent myths were that contraceptive pills cause severe headache $(86 \%$ in rural and $95 \%$ in urban communities), anaemia (55\% and $53 \%)$, sterility $(20 \%$ and $37 \%)$, breast cancer $(21 \%$ and $16 \%$ ) and birth defects (17\% and $11 \%)(15)$.

Therefore, the current study aimed to assess the prevalence of myths about various modern contraceptive methods used by women in Minia governorate in Upper Egypt and evaluate their effect on ever and current use of 
modern and traditional contraceptives. It is hypothesized that myths about contraceptives in such communities could be influencing women's choice about family planning options.

\section{Methods}

\section{Study design and place}

This was a cross-sectional study of married women aged 18-49 years recruited during their visits to the 10 accredited urban and rural health centres (eight urban and two rural) in Minia. These centres are accredited by the Egyptian Ministry of Health and Population to provide specific maternal and child health services. Minia is an Upper Egypt governorate with about 5.6 million inhabitants and an area of $30000 \mathrm{~km}^{2}$. The fertility rate in Minia according to the most recent census data was 3.8 per 1000 women aged 15-49 years (2). The uptake of contraceptives in Minia in 2015 was $37 \%$ for intrauterine devices (IUDs), $31 \%$ for oral contraceptives and $20 \%$ for injectables, with an overall prevalence of contraceptive use of $53 \%$ (4). These rates are comparable to national figures in 2014, which were $30 \%$ for the IUD, $16 \%$ for oral contraceptives and $9 \%$ for injectables, with an overall contraceptive prevalence of $59 \%(1)$.

\section{Study sample}

The study population was married women aged 1849 years. All women visiting the selected health centres seeking maternal and child health services and family planning services from June to December 2015 were approached by trained data collectors from the Public Health Department at Minia University and fourth-year medical students and invited to participate after giving verbal consent. If they agreed, they were interviewed at that time and interviews took about 10-15 minutes. Exclusion criteria were unmarried females, pregnant women, women aged $<18$ or $>49$ years, women who did not give their consent, and duplicate observations for women who visited the same or other centres more than once in the study period.

\section{Structured interview questionnaire}

Data were collected about the participants' sociodemographic characteristics, reproductive history, ever and current use of modern and traditional contraceptive methods and belief in seven myths about modern contraceptives using a structured interview questionnaire in Arabic (4). We tested the reliability of the questionnaire in a pilot study of 50 women.

Modern contraceptives included oral birth control pills, IUDs and injectables; traditional contraceptives included methods based on fertility awareness, such as calendar and lactational amenorrhea, and the withdrawal method. Due to the small number of participants who reported the use of barrier methods (five for condoms and three for diaphragms), we added these to the traditional methods category and labelled the group "traditional and barrier methods".

\section{Myths and misconceptions about contraceptives}

A pilot study including 50 women from two health centres (one rural and one urban) was carried out to assess the contraceptive prevalence rate and non-medical factors associated with their use. Women were asked to freely report any fears and rumours about contraceptives that they had heard or that were circulating in their communities or families. Based on the myths reported by the women in the pilot study, seven that were frequently reported and related to the three main modern contraceptive methods available in Egypt (oral contraceptives, IUDs and injectables) were included in the main questionnaire. The myths were: oral birth control pills cause cancer, IUDs can penetrate the uterus and travel up to the heart, injectables cause permanent infertility, difficulty in getting pregnant after stopping the use of contraceptives, contraceptives adversely affect women's health, contraceptives are for older women only, and contraceptive use increases the risk of fetal defects.

\section{Statistical analysis}

SPSS, version 20 was used for data entry and analysis. Characteristics of the women who had and did not have misconceptions about contraceptives were expressed as number and percentage or mean and standard deviation (SD). Chi-squared and t-tests were used to assess statistically significant differences in characteristics. The frequency of belief each of the seven myths was categorized according to women's use of contraceptives: never (used contraceptives, modern or traditional), ever (used contraceptives at some time), and current users. Multivariable logistic regression analysis was used to assess the association between misconceptions about contraceptives and current and ever use of oral birth control pills, IUDs, injectables and total traditional and barrier methods. Odds ratios (ORs) and 95\% confidence intervals (95\% $\mathrm{CI})$ were adjusted for: age, age at menarche, at marriage and at first baby, number of children, desired number of children, woman's education and occupation, husband's education and occupation, residence and decision-maker on the use of contraceptives In addition, the effect of increasing number of myths believed (1, 2, 3 and $\geq 4$ myths versus none) on contraceptive use was evaluated. $P<0.05$ was considered statistically significant.

\section{Ethical considerations}

Approvals to conduct the study were obtained from the Egyptian Ministry of Health and Population and the managers of the health centres. The Ethical Committee of Minia University granted ethical approval for this research. Women gave their verbal consent to participate.

\section{Results}

We approached 2021 women at the health centre in the study period; 1504 met our inclusion criteria (married, not-currently pregnant, seeking maternal and child health services and family planning services, aged 18 to 49 years). Of these women eligible for inclusion, 1212 


\begin{tabular}{|c|c|c|c|}
\hline $\begin{array}{l}\text { Sociodemographic and reproductive } \\
\text { characteristics }\end{array}$ & $\begin{array}{l}\text { Women with false } \\
\text { beliefs }(n=1075)\end{array}$ & $\begin{array}{l}\text { Women without false } \\
\text { beliefs }(n=137)\end{array}$ & P-value ${ }^{a}$ \\
\hline & No. (\%) & No. (\%) & \\
\hline Residence & & & $<0.001$ \\
\hline Rural & $531(92.5)$ & $43(7.5)$ & \\
\hline Urban & $544(85.3)$ & $94(14.7)$ & \\
\hline Education & & & $<0.001$ \\
\hline Illiterate & $394(91.4)$ & $37(8.6)$ & \\
\hline Read and write/primary school & $149(96.1)$ & $6(3.9)$ & \\
\hline Middle/secondary school & $422(82.6)$ & $89(17.4)$ & \\
\hline University or higher & $110(95.7)$ & $5(4.3)$ & \\
\hline Has a paid job & & & 0.04 \\
\hline Yes & $106(93.8)$ & $7(6.2)$ & \\
\hline No & $969(88.2)$ & $130(11.8)$ & \\
\hline Husband's education & & & $<0.001$ \\
\hline Illiterate & $268(92.4)$ & $22(7.6)$ & \\
\hline Read and write/primary school & $159(96.4)$ & $6(3.6)$ & \\
\hline Middle/secondary school & $533(84.3)$ & $99(15.7)$ & \\
\hline University or higher & $115(92.0)$ & $10(8.0)$ & \\
\hline Husband's occupation & & & 0.06 \\
\hline Unemployed & $26(100)$ & $0(0.0)$ & \\
\hline Manual worker & $139(89.1)$ & $17(10.9)$ & \\
\hline Private sector/freelance worker & $613(89.8)$ & $70(10.2)$ & \\
\hline Government employee & $297(85.6)$ & $50(14.4)$ & \\
\hline Decision-maker on use of contraceptives & & & $<0.001$ \\
\hline Woman herself & $123(75.5)$ & $40(24.5)$ & \\
\hline Husband & $47(78.3)$ & $13(21.7)$ & \\
\hline Joint & $905(91.5)$ & $84(8.5)$ & \\
\hline Contraceptive use & & & $<0.001$ \\
\hline Never & $96(100.0)$ & $0(0.0)$ & \\
\hline Ever & $979(87.7)$ & $137(12.3)$ & \\
\hline Current & $544(84.5)$ & $100(15.5)$ & \\
\hline Current use of & & & $<0.001$ \\
\hline Oral pills & $166(83.4)$ & $33(16.6)$ & \\
\hline Intrauterine devices & $195(81.9)$ & $43(18.1)$ & \\
\hline Injectables & $116(89.9)$ & $13(10.1)$ & \\
\hline \multirow[t]{2}{*}{ Traditional and barrier methods } & $67(85.9)$ & $11(14.1)$ & \\
\hline & Mean (SD) & Mean (SD) & \\
\hline Age (years) & $29.9(8.3)$ & $32.0(7.4)$ & 0.02 \\
\hline Age at menarche (years) & $13.0(1.3)$ & $13.4(1.0)$ & 0.02 \\
\hline Age at marriage (years) & $18.9(3.0)$ & $19.6(2.6)$ & 0.19 \\
\hline Age at first birth (years) & $20.5(3.1)$ & $20.3(2.1)$ & $<0.001$ \\
\hline Number of children & $2.5(1.4)$ & $2.7(0.9)$ & 0.48 \\
\hline Number of desired children & $3.4(1.3)$ & $3.5(0.7)$ & 0.12 \\
\hline
\end{tabular}

SD: standard deviation.

${ }^{a}$ Chi-squared test for categorical variables and independent sample t-test for continuous variables.

consented to participate, giving a response rate of $81 \%$. As shown in Table 1, 1075 women (88.7\%) believed myths about contraceptives. Women with misconceptions about contraceptives were younger and had younger age at menarche but were older at the time of the birth of their first child when compared with those without such miscon- 


\begin{tabular}{|c|c|c|c|c|}
\hline \multirow[t]{2}{*}{ Myths about contraceptives } & $\begin{array}{c}\text { Total } \\
(n=1212)\end{array}$ & $\begin{array}{l}\text { Never users } \\
\quad(n=96)\end{array}$ & $\begin{array}{l}\text { Ever users } \\
(n=1116)\end{array}$ & $\begin{array}{l}\text { Current users } \\
\quad(n=644)\end{array}$ \\
\hline & No. (\%) & No. (\%) & No. (\%) & No. (\%) \\
\hline Birth control pills cause cancer & $926(76.4)$ & $68(70.8)$ & $858(76.9)$ & $479(74.4)$ \\
\hline $\begin{array}{l}\text { The intrauterine device can travel up to the heart by } \\
\text { penetrating the uterus }\end{array}$ & $568(46.9)$ & $56(58.3)$ & $512(45.9)$ & $293(45.5)$ \\
\hline Injectables cause infertility & $335(27.6)$ & $65(67.7)$ & $270(24.2)$ & $167(25.9)$ \\
\hline Contraceptives are for older women only & $91(7.5)$ & $18(18.8)$ & $73(6.5)$ & $34(5.3)$ \\
\hline Contraceptives adversely affect women's health & $108(8.9)$ & $5(5.2)$ & $103(9.2)$ & $72(11.2)$ \\
\hline $\begin{array}{l}\text { It is very difficult to get pregnant after stopping using } \\
\text { contraceptives }\end{array}$ & $114(9.4)$ & $19(19.8)$ & $95(8.5)$ & $61(9.5)$ \\
\hline Contraceptives use results in birth defects in babies & $85(7.0)$ & $6(6.3)$ & $79(7.1)$ & $45(7.0)$ \\
\hline
\end{tabular}

ceptions. A greater proportion of rural than urban women and women whose husbands were unemployed than whose husbands had a job had misconceptions about contraceptives. Of ever and current users of contraceptives, $137(12.3 \%)$ and $100(15.5 \%)$ respectively reported no misguided beliefs, while all women who had never used contraceptives $(96,100 \%)$ reported believing one or more myths about contraceptives. The 96 never users, had a higher mean of number of desired children (3.7 children) compared with ever contraceptive users ( 3.3 children). In addition, although never users were four years younger than contraceptive users, their mean number of children (2.5 children) did not differ greatly from that of contraceptive users (2.4 children), which suggests repeated pregnancies and deliveries. Eleven women (14.1\%) who were currently using traditional or barrier contraceptive methods had no misconceptions about contraceptives compared with 33 (16.6\%), 43 (18.1\%) and 13 (10.1\%) of current users of oral birth control pills, IUDs and injectables, respectively.

Table 2 shows responses to seven myths about contraceptives among never, ever and current contraceptive users and the total sample of women. The most prevalent myth about contraceptives was that birth control pills cause cancer which was expressed by 926 women (76.4\% of the total sample), followed by the misconception that IUDs can travel up to the heart by penetrating the uterus - 568 (46.9\%) of the women. A greater proportion of never users of contraceptives believed the myths than ever and current users.

The multivariable logistic regression analysis of the association between misconceptions about modern contraception and ever use and current use of modern and traditional contraceptives is shown in Table 3. Women who have ever used any contraceptive method, and specifically birth control pills, were less likely to believe myths about contraceptives (OR $=0.79 ; 95 \% \mathrm{CI}$ : $0.65-0.89$ and $\mathrm{OR}=0.40 ; 95 \% \mathrm{CI}$ : $0.26-0.61$ respectively). However, women who had ever used traditional and barrier methods had about twice the odds of believing myths than those who had not used these methods, but this difference was not statically significant $(\mathrm{OR}=2.32$;
95\% CI: 0.92-7.47). Among current contraceptive users, women using any method, birth control pills and IUDs were less likely to believe myths about contraceptives, OR $=0.31$ (95\% CI: 0.20-0.47), OR = 0.59 (95\% CI: $0.37-0.90)$ and $\mathrm{OR}=0.50$ (95\% CI: 0.34-0.76) respectively (Table 3).

The association between believing myths and type of contraceptive used showed a dose-response pattern with belief in an increasing number of myths about contraceptives (Table 4).

\section{Discussion}

To the best of our knowledge, this is the first study to measure the prevalence of myths about contraceptives among women in Upper Egypt, and the first to evaluate the effect of those myths on ever and current use of contraceptives. According to our findings, myths about contraceptives were prevalent; $88.7 \%$ of the women had misconceptions, mainly the belief that oral birth control pills caused cancer and that IUDs can penetrate the uterus and move to the heart. Accordingly, the ever use of oral contraceptives and current use of oral contraceptives and IUDs were lower and the ever use of traditional and barrier contraceptives was higher in women who believed in such myths about contraceptives compared with women who did not.

Challenging traditional customs and fertility habits by encouraging people to use contraceptives has always faced resistance $(5,6,11-16)$. Because of the wide gap between scientific evidence and public perception of the safety of contraceptives, one path of resistance to contraceptive use was the ready spread of health-related myths about contraceptives in Egypt $(13,14)$. Similar to our findings, these myths were prevalent and impeded the use of contraceptives in Senegal, Nigeria and Kenya (11), Ghana (12,17), India (18), Malawi (19), Nigeria (20) and many other countries as reported in two previously published reports $(7,8)$.

Ever and current use of oral birth control pills was significantly lower in women in Minia who believed in myths about contraceptives. This is plausible given that the most prevalent myth about contraceptives reported by over three quarters of those women was 


\begin{tabular}{|c|c|c|c|c|}
\hline Contraceptive use & Beta & SE & $P$-value & OR $(95 \% C I)^{a}$ \\
\hline \multicolumn{5}{|l|}{ Current use of: } \\
\hline \multicolumn{5}{|l|}{ Any contraceptives } \\
\hline Crude model & -0.97 & 0.20 & $<0.001$ & $0.38(0.26-0.56)$ \\
\hline Adjusted model $^{\mathrm{b}}$ & -1.17 & .224 & $<0.001$ & $0.31(0.20-0.47)$ \\
\hline \multicolumn{5}{|l|}{ Birth control pills } \\
\hline Crude model & -0.55 & 0.22 & 0.01 & $0.58(0.38-0.88)$ \\
\hline Adjusted model $^{\mathrm{b}}$ & -0.52 & 0.25 & 0.03 & $0.59(0.37-0.90)$ \\
\hline \multicolumn{5}{|l|}{ Intrauterine device } \\
\hline Crude model & -0.73 & 0.20 & $<0.001$ & $0.48(0.33-0.72)$ \\
\hline Adjusted model $^{\mathrm{b}}$ & -0.69 & 0.24 & $<0.001$ & $0.50(0.34-0.76)$ \\
\hline \multicolumn{5}{|l|}{ Injectables } \\
\hline Crude model & 0.14 & 0.31 & 0.64 & $1.15(0.63-2.11)$ \\
\hline Adjusted model $^{\mathrm{b}}$ & 0.04 & 0.34 & 0.99 & $1.04(0.54-2.03)$ \\
\hline \multicolumn{5}{|c|}{ Traditional and barrier methods } \\
\hline Crude model & -0.27 & 0.34 & 0.42 & $0.76(0.39-1.48)$ \\
\hline Adjusted model ${ }^{b}$ & -0.12 & 0.38 & 0.79 & $0.88(0.42-1.54)$ \\
\hline \multicolumn{5}{|l|}{ Ever use of: } \\
\hline \multicolumn{5}{|l|}{ Any contraceptives } \\
\hline Crude model & -0.19 & 0.39 & 0.01 & $0.82(0.68-0.91)$ \\
\hline Adjusted model $^{\mathrm{b}}$ & -0.23 & 0.52 & $<0.001$ & $0.79(0.65-0.89)$ \\
\hline \multicolumn{5}{|l|}{ Birth control pills } \\
\hline Crude model & -0.75 & 0.19 & $<0.001$ & $0.47(0.33-0.68)$ \\
\hline Adjusted model ${ }^{\mathrm{b}}$ & -0.91 & 0.22 & $<0.001$ & $0.40(0.26-0.61)$ \\
\hline \multicolumn{5}{|l|}{ Intrauterine device } \\
\hline Crude model & 0.28 & 0.23 & 0.22 & $1.33(0.85-2.08)$ \\
\hline Adjusted model ${ }^{\mathrm{b}}$ & 0.33 & 0.26 & 0.19 & $1.39(0.88-2.26)$ \\
\hline \multicolumn{5}{|l|}{ Injectables } \\
\hline Crude model & -0.08 & 0.19 & 0.68 & $0.92(0.64-1.35)$ \\
\hline Adjusted model ${ }^{\mathrm{b}}$ & 0.09 & 0.23 & 0.20 & $0.91(0.58-1.42)$ \\
\hline \multicolumn{5}{|c|}{ Traditional and barrier methods } \\
\hline Crude model & 1.04 & 0.52 & 0.05 & $2.82(1.02-7.81)$ \\
\hline Adjusted model $^{\mathrm{b}}$ & 0.84 & 0.60 & 0.18 & $2.32(0.92-7.47)$ \\
\hline
\end{tabular}

SE: standard error; OR: odds ratio; CI: confidence interval.

aThe reference category was women who did not belief in myths.

${ }^{b}$ Adjusted for age, age at menarche, at marriage and at first baby, number of children, desired number of children, woman's education and occupation, husband's education and occupation, residence and decision-maker on use of contraceptives.

that oral contraceptives cause cancer. Since they became available in the 1960s, oral contraceptives have been the most stigmatized contraceptive method as result of disinformation and myths. Such falsehoods started in the 1980s with the rumour that oral contraceptives cause "weakness" (13), a non-medical based condition of lethargy, dizziness and fatigue associated with contraceptive pill use, and the myth was prevalent in Egypt (13), Botswana and the Islamic Republic of Iran (21). Other myths reported worldwide include the association between the oral contraceptives and ovarian, endometrial and breast cancer (22).

Despite the scientific evidence that IUDs are one of the safest forms of contraceptive (23), and its discontinuation rate is the lowest among contraceptive users in Egypt $(1,4)$, the second most prevalent myth about contraceptives in women in Minia was that IUDs can travel up to the heart by penetrating the uterus. The current use of IUDs was 50\% lower among women who believed this myth. Similar misrepresentations have been important barriers to IUD uptake in other low- and middle-income countries $(7,8,24)$.

The use of oral birth control pills and IUDs decreased as the number of myths believed by women about contraceptives increased, while the ever use of traditional and barrier contraceptives increased among those who 


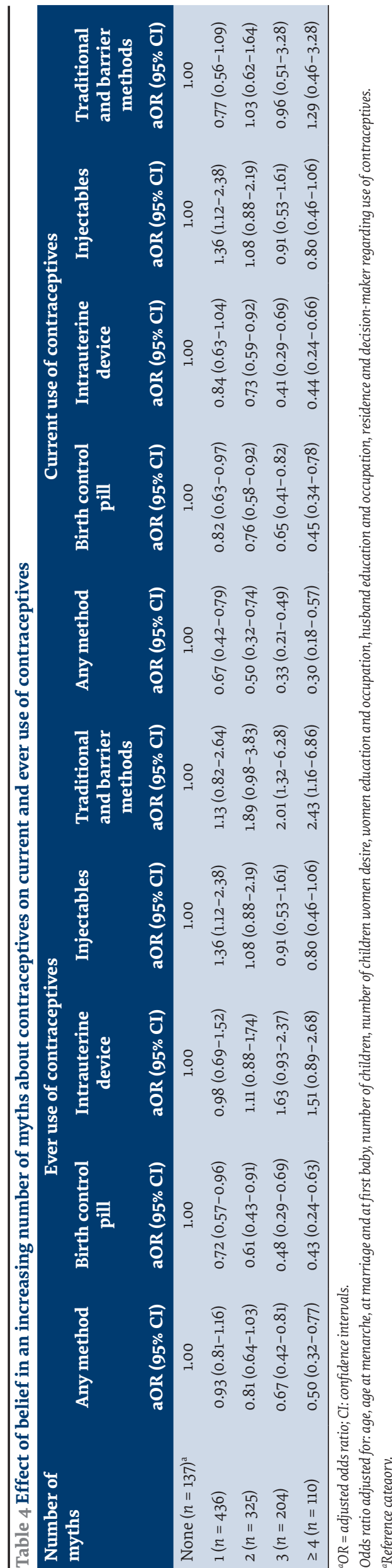

believed such myths. Women with lower levels of education also preferred traditional health practices to modern ones, and perception of such modern methods was affected by doubts regarding its safety.

Previous research has pointed to the non-contraceptive health benefits of modern contraceptive use on women's health such as alleviating uncomfortable menstruation symptoms (heavy, painful and irregular periods), improving acne and hirsutism, treating endometriosis and reducing the risk of endometrial and ovarian cancers $(5,9)$, their effect on uncontrolled fertility rates and the resulting improved family welfare $(5,9)$. Unfortunately, the high prevalence of contraceptives myths found in Upper Egypt suggests poorer health status, high fertility rates and other adverse effects on the family of our studied women $(7,8)$. Further research on these effects is needed, especially as the women with misguided beliefs about contraception tended to want a higher number of children.

It is clear that myths were widely circulated and persisted even among women who were using modern contraceptives. All the women who never used contraceptives reported believing in all or some of the myths, but data were not available on when they heard to rumours - before or after marriage for example - and how long they had for believed in them. However, a report from eight low- and middle-income countries, including Egypt, showed no difference in the rate of contraceptive use with different durations of belief in the myths (15). In addition, another study showed that the duration of oral contraceptive use did not influence the prevalence of misconceptions about the birth control pills (21).

This study only included women from one governorate of Upper Egypt which could affect the generalizability of the study findings; however, our sample of urban and rural women was large. A review has shown that male respondents in many studies have reported myths about condoms such as weakening the penis, causing impotence or reducing pleasure (8). We did not look at myths about male contraceptive methods including condoms. Very few participants in the current study reported using condoms as a contraceptive method and such myths might be associated with this low use. Future studies to include the experience of both men and women about male methods of contraception are needed.

\section{Conclusion}

The belief in myths about contraceptives is common in Minia and was associated with lower use of modern contraceptive methods, especially oral contraceptive pills and IUDs, but higher use of traditional methods of contraception. Reproductive health programmes to refute myths and misguided beliefs about modern contraceptives may help increase the use of modern contraceptive methods and are recommended, along with continuous provision of such contraceptives. Suggestions have been made for mass media and family planning health campaigns to improve awareness about the benefits of modern contraceptives and to change social norms about their use (25). 
However, training of reproductive health service providers to interact with and respond to incorrect information held by clients is recommended. These health service providers can also involve the community through counsel-

\section{Acknowledgements}

We thank all the workers in the health centres of the study.

Funding: None.

Competing interests: None declared. ling sessions and seminars, which include satisfied contraceptive users to share their experiences, to help dispel pervasive myths in their local communities.

\section{Mythes concernant les méthodes de contraception modernes et traditionnelles entretenus par les femmes de Minya en Moyenne-Égypte}

\section{Résumé}

Contexte : Les idées fausses concernant les méthodes contraceptives modernes ont une incidence sur leur utilisation dans les pays à revenu faible et intermédiaire.

Objectifs : La présente étude avait pour objectif de déterminer la prévalence des mythes concernant les méthodes contraceptives modernes et leur association avec une utilisation de contraceptifs, antérieure ou au moment de la réalisation de l'étude, par les femmes de Minya en Moyenne-Égypte.

Méthodes : Il s'agissait d'une étude transversale portant sur 1212 Égyptiennes mariées, âgées de 18 à 49 ans, fréquentant les centres de santé des zones urbaines et rurales de Minya. Les données ont été recueillies à l'aide d'un questionnaire d'entretien structuré et traitées dans le cadre d'une analyse de régression logistique ; les odds ratios (OR) et les intervalles de confiance à $95 \%$ (IC) ont été calculés.

Résultats : La plupart des femmes (88,7\%) avaient une ou plusieurs idées fausses sur les méthodes de contraception. Les idées les plus répandues étaient que la pilule contraceptive provoque des cancers et que les dispositifs intra-utérins (DIU) peuvent perforer l'utérus et migrer vers le cœur. Le taux d'utilisation de la pilule contraceptive et des DIU au moment de l'étude était significativement plus faible chez les femmes ayant des croyances erronées que chez celles qui n'en avaient pas, OR ajusté $=0,59$ (IC à $95 \%: 0,37-0,90$ ) et OR ajusté $=0,50$ (IC à 95\%:0,34-0,76) respectivement. La croyance dans un nombre de plus en plus important de mythes était associée à une probabilité plus faible d'un éventuel recours à la pilule contraceptive : OR = 0,72 (IC à $95 \%: 0,57-0,96), O R=0,61 ;$ IC à 95\%:0,43-0,91), OR=0,48 (IC à 95\%:0,29-0,69) et $\mathrm{OR}=0,43$ (IC à $95 \%$ : 0,24-0,63) chez les femmes ayant un nombre d'idées fausses égal à 1, 2, 3 ou supérieur ou égal à 4 comparativement à celles qui n'en avaient aucune.

Conclusions : Les mythes concernant les moyens de contraception sont largement répandus chez les femmes de Minya et peuvent avoir une incidence notable sur le choix et l'utilisation d'une méthode contraceptive. Il est recommandé de mettre en place des programmes de santé génésique permettant de réfuter ces croyances erronées.

$$
\begin{aligned}
& \text { الأساطير حول مو انع الحمل الحديثة والتقليدية في صفوف السيدات في محافظة المنيا، صعيد مصر } \\
& \text { إبهاب إسبحة } \\
& \text { الخالاصة } \\
& \text { الخلفية: تؤثر المفاهيم المغلوطة بشأن موانع الحمل على استخدامها في البلدان المنخفضة والمتوسطة الدخل. } \\
& \text { الأهداف: هدفت هذه الدراسة إلى تحديد معدل انتشار الأساطير حول موانع الحمل الحديثة واقترانها بالاستخدام السابق والحالي لمو انع الحمل في }
\end{aligned}
$$

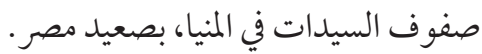

$$
\begin{aligned}
& \text { طرق البحث: شملت هذه الدراسة المقطعية } 1212 \text { سيدة مصرية متزوجة تتراوح أعمارهن بين } 18 \text { و } 49 \text { سنة منن يترددن على المراكز الصحية }
\end{aligned}
$$

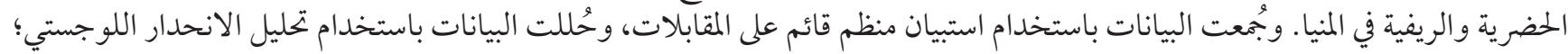

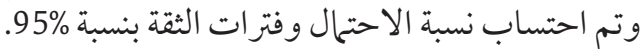

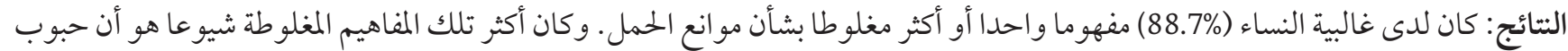

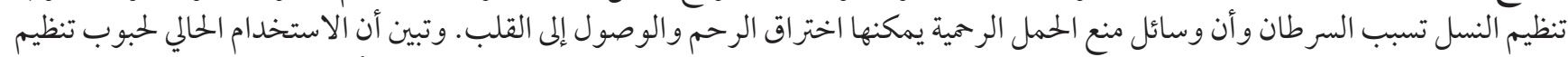

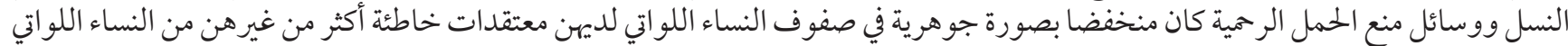

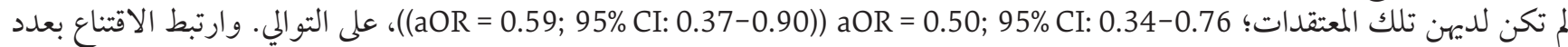

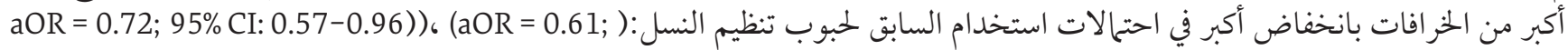

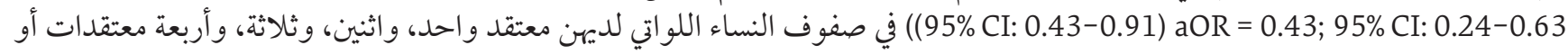




$$
\begin{aligned}
& \text { أكثر، في مقابل النساء اللواتي ليست لديهن أية معتقدات مغلوطة على الإطلاق. }
\end{aligned}
$$

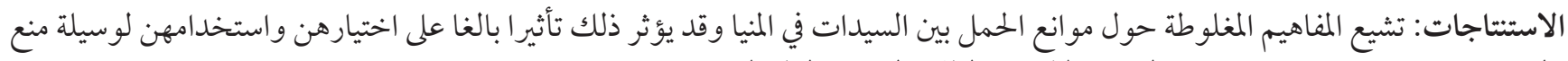

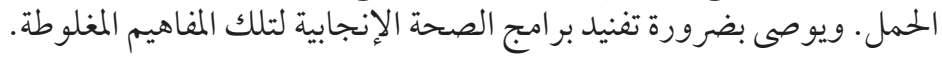

\section{References}

1. El-Zanaty F, Way A. Egypt demographic and health survey, 7th ed. Cairo: Ministry of Health and Population, National Population Council Press; 2014.

2. CAPMAS 2019 Demographic indicators. Cairo: Central Agency for Public Mobilization and Statistics (CAPMAS); 2019.

3. Practice guidelines for family physicians. In: Family planning. Second edition. Cairo: Ministry of Health and Population; 2004:27-47.

4. Eshak ES, Sayed SI, Kamel EG, El-Sheref MA. Non-medical predictors for ever and current use of contraceptives among women in Minia, Upper Egypt. J Public Health. 2018;26:663-71. https://doi.org/10.1007/s10389-018-0912-x

5. Tyrer L. Introduction of the pill and its impact. Contraception. 1999;59:11S-16S. https://doi.org/10.1016/s0010-7824(98)oo131-0

6. Contraceptive myths and counseling messages. Baltimore: INFO Project, Johns Hopkins Bloomberg School of Public Health and International Planned Parenthood Federation; 2007 (https://www.k4health.org/toolkits/iud/contraceptive-myths-and-counseling-messages, accessed 3 December 2019).

7. Russo JA, Miller E, Gold M A. Myths and misconceptions about long-acting reversible contraception (LARC). J Adolesc Health. 2013;52(4 Suppl):S14-21. https://doi.org/10.1016/j.jadohealth.2013.02.003

8. Eram U. Myths and beliefs about contraceptive methods: a review article. Saudi J Med Pharm Sci. 2017;3(1):9-12. DOI: 10.21276/ sjmps.2017.3.2

9. ESHRE Capri Workshop Group. Noncontraceptive health benefits of combined oral contraception, Hum Reprod Update. 2005;11(5):513-25. https://doi.org/10.1093/humupd/dmio19

10. Radovich E, el-Shitany A, Sholkamy H, Benova L. Rising up: Fertility trends in Egypt before and after the revolution. PLoS One. 2018;13(1):e0190148. https://doi.org/10.1371/journal.pone.0190148

11. Gueye A, Speizer IS, Corroon M, Okigbo CC. Belief in family planning myths at the individual and community levels and modern contraceptive use in urban Africa. Int Perspect Sex Reprod Health. 2015;41(4):191-9. https://doi.org/10.1363/4119115

12. Sakara A, Namoog MY, Badu-Nyarko SK. Misconceptions and rumours about family planning among Moslem males in Tamale Metropolis, Ghana. Glob J Interdiscip Soc Sci. 2014;4(1):9-14. http://197.255.68.203/handle/123456789/7898

13. DeClerque J, Tsui AO, Abul-Ata MF, Barcelona D. Rumor, misinformation and oral contraceptive use in Egypt. Soc Sci Med. 1986;23(1):83-92. https://doi.org/10.1016/0277-9536(86)90327-8

14. Private Practitioner Family Planning Project. Family planning dialogue. Rumors of contraception: myths vs facts. New Egypt J Med. 1990;4(2 Suppl):1-21.

15. Grubb GS. Women's perceptions of the safety of the pill: a survey in eight developing countries. J Biosoc Sci. 1987;19(3):313-21. https://doi.org/10.1017/s0021932000016965

16. Paz Soldan V A. How family planning ideas are spread within social groups in rural Malawi. Stud Fam Plan. 2004;35(4):275-90. https://doi.org/10.1111/j.0039-3665.2004.00031.x

17. Hindin MJ, McGough LJ, Adanu R M. Misperceptions, misinformation and myths about modern contraceptive use in Ghana. J Fam Plan Reprod Health Care. 2014;40(1):30-5. https://doi.org/10.1136/jfprhc-2012-100464

18. Shubhra A, Najam R, Agarwal A. A clinical study on social stigma and trends of contraception at a tertiary care centre. Int J Reprod Contracept, Obstet Gynecol. 2016;5(12):4271-4. https://doi.org/10.18203/2320-1770.ijrcog20164326

19. Chipeta EK, Chimwaza W, Kalilani-Phiri L. Contraceptive knowledge, beliefs and attitudes in rural Malawi: misinformation, misbeliefs and misperceptions. Malawi Med J. 2010;22(2):38-41. https://doi.org/10.4314/mmj.v22i2.58790

20. Ankomah A, Anyanti J, Oladosu M. Myths, misinformation, and communication about family planning and contraceptive use in Nigeria. Open Access J Contracept. 2011;2(1):95-105. https://doi.org/10.2147/oajc.s20921

21. Hamani Y, Sciaki-Tamir Y, Deri-Hasid R, Miller-Pogrund T, Milwidsky A, Haimov-Kochman R. Misconceptions about oral contraception pills among adolescents and physicians. Hum Reprod. 2007;22(12):3078-83. https://doi.org/10.1093/humrep/dem259

22. Ali SH, Abass IM. Misconceptions about oral contraceptive pill used among women at primary health care centers in Holy Karbala city. IOSR J Nurs Health Sci. 2015;4(6):70-7. https://doi.org/10.9790/1959-04637077

23. Ali MM, Sadler RK, Cleland J, Ngo TD, Shah I H. Long-term contraceptive protection, discontinuation and switching behaviour: intrauterine device (IUD) use dynamics in 14 developing countries. London: World Health Organization and Marie Stopes International; 2011. 
24. Robinson N, Moshabela M, Owusu-Ansah L, Kapungu C, Geller S. Barriers to intrauterine device uptake in a rural setting in Ghana. Health Care Women Int. 2016;37(2):197-215. https://doi.org/10.1080/07399332.2014.946511

25. Hutchinson PL, Meekers D. Estimating causal effects from family planning health communication campaigns using panel data: the "your health, your wealth" campaign in Egypt. PLoS One. 2012;7(9):e46138. https://doi.org/10.1371/journal.pone.0046138 